\title{
The Role of Business Management with Historical and Global Perspective
}

\author{
Iqbal Shaukat \\ Canadian Association of Post Doctoral Scholar, Toronto, Canada
}

\section{Email address:}

professionalstudent2020@gmail.com

\section{To cite this article:}

Iqbal Shaukat. The Role of Business Management with Historical and Global Perspective. International Journal of Management and Fuzzy Systems. Vol. 7, No. 3, 2021, pp. 55-63. doi: 10.11648/j.ijmfs.20210703.13

Received: July 23, 2021; Accepted: August 4, 2021; Published: August 27, 2021

\begin{abstract}
Management is very important for every person, society. With the help of management Qualifications we can achieve the goal of economic development. The role of business management education is very important in various ways. We can make planning with the Tool of master, increment, Capital budget. With the practice business management. With the help of practice of business management Qualification we can scan the idea easily and development of product according to need of time period. With the help of best practice of business management qualification we can run every system effectively, which is introduced in market for the innovation and development. We can analyze the strength and weakness. Business management help how We can analyze the market situation, because the best practice of business management. Good decision-making is also part of business management. We can adopt good alternatives during business decision. Because of practice management qualification we can design the best organizational structure and set up and matrix. During the practice of business management qualifications We can control our mistake and maintain and stander of quality control. Good economic policis can give the good prosperous future. When one country not avhieved the goal of economic development such countries face disaster in every sector, as a consequence whole nation wil face 1 economic and political unrest. In the light of all arguments we can say prosperous economic future is only only possible with economic growth and Devlopment.
\end{abstract}

Keywords: Business, Management, Perspective

\section{Historical Perspective}

Business management is the integral part of our corporate world. Success full business can be run only with the help of business management. In the early age man doing the business for earning and necessity. With the passage of time the man regularized the all the trade. In eighteen century many business institutes -came in being. In 1819 the first business came in to being in France. In 1857 in hungry Budapest. In USA The Hass Business school came Into being in 1898 in university of California and Watson school came in to being in Pennsylvania USA 1898. The Harvard university established started master's program and establish research center regarding the Business management studies in1908. In 1916 university of Chicago started the Doctorate (PHD) program. In 1946 first business school in Indian state Jharkhand. In the $17 \& 18$ Century colonization of various part of world expended by few countries. Many multinationals was established during the eighteen century. For example
Nestle, Lever Brothers, City, Colgate, and Barclay The role of business is very important in various ways. We can make planning with the Tool of master, increment, Capital budget. With the practice business management. With the help of practice of business management we can scan the idea easily and development of product according to need of time period. With the best practice of business management we can run every system effectively which is introduced in market for the innovation and development such as ERPS [1-5].

\section{Practical Approach}

Can conduct the SWOT analysis in which we can analyze the strength and weakness with the help of business management. We can analyze the market situation with the best practice of business management. Good decisionmaking is also part of business management. We can adopt good alternatives in our business decision. Because of practice management we can design the best organizational 
structure and set up and matrix. During the practice of business management. We can control our mistake and maintain and stander of quality control. We can analyze our stander with random sample Bases with the help of the best business practice. Business management can be beneficial for forecasting regarding business, with the practice of business management. We can forecast by qualitative and qualitative ways. Business management can play the vital role in material management including supply chain management. Stock piles buying. Inventory management. The Best production management can optimized the resource because of best practice business management. The Best method of production can be implemented with the best practice of business management. For example push back production method can be practiced with the help of business management. For example in various developed countries like japan role of business management is very high. In japan every decision of organization is taken with the stance of business management. Japanese practice the concept of business management in every sector [2-12].

\section{Education Perspective}

In USA the better style of business management implemented with the intention of high level of output and growth of economy. In various developed countries promotion of business education is very vital. In developed countries Business management courses are the essential part of curriculum. That is why they produce the people who practicing the business management very wall. In USA Harvard business research are very use full for the business graduates and practicing business consultant. All thedeveloped countries should help the least developed countries and developing countries for the promotion of business management education. All government of the developing countries should establish the institution which give the management education all professional levels. Economic and finance ministry of all developing countries should establish such publication institution who have right publish of business research which are conducted in various famous university of world. Thus, we can say that role of business management in one country is very important. Business management education can be broken the vicious circle of poverty in the various countries around the world Customer satisfaction is the important part of business management with the help of business we can design the product according to the desire of customer we arrange the conferences and survey qualitative and quantitative we arrange the conference regarding the promotion of product. Because of business management we design such strategy which is according to the wishes of customer and satisfaction with the help of business management we protect the copy right and patent right. With the the help of business management we maintain the equity of brand. Because of business management we analyze the concept of testing and development of product. With the help of business management we organize the data of customer regarding the goods. With the help of good business management we organize the product line with organize such as web and telephone. With the help of good business management we save the product from monopoly effects and maintain the reputation of brands. Because of good business management the product is superior to other and superior quality product. when we adopt the good management style we will face the copy right issues. Withh the help of good business manaement we will get the better feed back of customer. Good business management give the trend of customer. Good business management give strategy how to response in the customer of need. With the help of good business management we can minimize the reservation of customer. With the help of good business management we can make the good sustainable and unique in the market. With the help of good business management we can make the beta analyst. The benefit of beta analyze we can update the customer behavior and trends. With the help of business management we can conduct the five-forces analyze portal marketing and industrial research. With the help of that we can aware from marketing situation and industrial situation. Inustrial situation help you maintain the situation regarding the all type of good which is related to consumers. With the good business management we can face dumping situation from any country of the world. with the help of vibrant good business we can establish the good distribution channel of good. Horizontal and vertical are the main class of channel distribution These channel have own merits and demerits but due to the management system we can organize according to demand and supply of goods. With the help of good management we can easily calculate the out of various out put channels of distribution. Better business management system give the frame work how to face the multiple situation of market; some time the demand are very high and some time demand are very low some time the supply us very high as against the situation in all such situation can create the panic for business, good business system give the frame work according to situation. Good business system provide the opportunity to access to market [2-9].

\section{With General Perspective}

With the help of good business system we can minimize our problems which we are facing in various situations and conditions. Good business system can give the strategy which can be superior to compilation. When we have the good competition strategy we can not be caliph in markett any time or in any situation. With the help of good management system we can accumulate the brand equity and positive market reputation. With the help of accumulated of brand we can access the realization of brand; Thus we can say that brand can be easily valued. The valuation of that we can easily calculation customer ship of brand. Good business management reduce the chance of disaster of brand of company. Good business management is the great frame work for the enterprises who enter the market newly who face the heavily competition in market and access the market 
according to the target of business planning. With the help of sound marketing system we can make the good policy of marketing orientation. Marketing orientation is a strategy which provide the power full tool to business. When we have the good management system we can adopt the good production concept according to the need and design of customers and maintain the market viable situation//when we make the production concept we consider one thing that customer should be satisfied. In good business management we cannot ignore the view and need of customers.

With the help of selling concept we can get the profit through advertising and other promotion tools., this is only that company can get the hand some profit this is the selling concept without the good selling concept we can maximize our profit. This is called the profit from volume. With the sound business management we can earn the lot of profit. With the help of good and sound marketing system we can implement marketing concept very easily. This the concept we can target the market and measure the need of customer. With the help of sound management system we can integrate the market. Wiith the help of sound marketing system we can better utilize all the sources of marketing for promotion and sales. This integration helps the increase the profitability of business. Marketing concept have lot of meaning. With the help of sound management we can implement the marketing according to the needs of customers. With the help sound management system we can measure the satisfaction of customer. Social concept is very important in marketing. Because of sound marketing system we can make the strategy according to the country population and needs. If one company not make the sales and marketing strategy according to the country economic system the company can face the disaster situation

With the help of sound management system we can all the integrated all the marketing functions according to needs. with the help of good management system we can create the good relationship with customer. With the help of good management we can supply the good on the regular basis. This is only possible when have the awareness all the concept of production concept selling concept and marketing concept and social. Environment factor are very effect on business with the help of sung business management we can control all the environmental factors. The environmental factors such as country population and national income per capita income and customs and social values. The other environmental factors like government regulations laws and labors and budget policy and competition among the market shares holders. Court of corporate governance is the example of external environmental tools. With the help of good business system we can adjust all the changes which is related to environments [2-16].

\section{Global Perspective}

With the help of sound business management we can easily understand all the changes of environments. Good management system provides path how to face the environmental challenges in various situations. With the help of sound business management we can decision with flexibility according to the requirement of business. With the help of good management system we can easily adopt the environment changes according to the national and international regulations and customs. With the help of good business management system we can broad cast all the information regarding the business according to the laws of country.

Some time government makes the various laws for various sectors, which should be obeyed by the company Thus we can say that environmental changes can be monitored with the help of good management system. Withh the help of good management system we can fulfil the stander of marketing environment fit. we can measure that we can take decision according to the environment stander. This stander provides the information that we successfully face the change in environment. With the help of sound system of management we can easily implement the concept of marketing Mix. which is the core of the marketing management. The four phase of the marketing mix Product, Place, Price, Promotion.

Product in which we decided what is the design and coupon and brand quality packaging functioning and style of product. With the help of sound business management we can arrange to the customer and brand needs without this concept product wan not be developed. In these days' product prize is very important because of this concept the management pay special priority to this segment. With the help of batter management the product concept properly implemented. The segment of marketing mix place where the product is display. In place, we decided where the product lunged. The place is very concept in marketing. For example with the help of place concept where the out lets are allowed to sell the product. Without the arrange of place the proper marketing strategy can not be implemented. Thus, we can say the good sound system is very viable in this regard. In the absent of sound management we can be decided good place for product Prize is the important price of marketing mix. Prize is the integral part of marketing operation. Without the prize we cannot the achieve the target in finance. In this segment we decide that is the actual price and discount policy. prize policy determine the profitability. If the company not decide the prize policy properly the company can face the financial crises. With the help of good business management policy we can achieve the prize target. The prize determination is the important segment of marketing. Promotion is the important part of marketing mix.

With the help of promotion we launch our product. Main tool of promotion sign board advertising on TV and newspaper and public city. With the help of advertising we can achieve the target of growth and promotion and development. With the help of batter management system we can achieve success in the promotion. Thus, we can say marketing mix is very important for every marketing professional and management consultant. Marketing mix is a concept which is learned by every management consultant. Marketing mix concept is the main tool of marketing 
organization. Business management have powerful in the marketing mix. Marketing plan is the important part of business strategy. Thus plan describe and explain the current marketing situation and expected result of all results. Identify all the resources will be needed at any time included financing and skills. Describe all the result all action which was mentioned in the marketing plan. With the help of business management we monitor all the result and overview the all steps. With the help of sound business management we can implement the marketing plan easily. In business management we consider all phases of business management. The impact of sound management system we can analyze the all the situation according to the current situations. In the present of sound business management we can design the strategic marketing plan. In strategic marketing plan we study all the aspect of marketing marketing leader. Marketing challenger. Market follower. Market niche. Wth the help of sound marketing management and business management we can prepare the strategy to face the market leader and marketing challenger and market followers. In good management we design such plan which is favorable for company and discourage the monopoly. Good management great the environment which is favorable for whole country and entire business system. Marketing segmentation is the important part of marketing world. In marketing segmentation we analyze all the aspects of market. When we make the marketing segmentation analyzation we make groupl according to the habits and religion and customs and political factor. In segmentation we divide the market in groups. In marketing segmentation we make reports and analyze them. we also consider the country political situation and climate conditions and economic growth and economic development. In segmentation we consider all variable which can creat the uncertain situation in the country. We consider all factor which creat the uncertainty in the country. In the marketing segmentation we make all plan with figure and diagram and table. All figures and diagram express all the situation which is present in the fields. With the help of sound management system we can make the marketing segmentation plan easily. Sound business management help the segmentation regarding implementation. With the help of good management system we can fellow all the reports and scenario. if we have not sound management we cannot the implement on the spirit of marketing segmentation. With the sound management system we can make the research strategy. With the help of good management system we can make the qualitative and quantitative strategy for the marketing segmentation. New product is the important part of business world. With the help of sound business management we creat the ideas. Idea generation is possible with the help of sound management system. Wiith the help of good management system we can idea scanning. Idea scanning is a only way gain the purity in idea. with the help of idea scanning this idea is viable. With the help of sound business management system the concept of development and testing is implemented. with the help of sound business system we can analyze the response of market. Commercialization of product. Price determination is the important part of business management. If we have to estimate the solvency position and debt equity ratio and regarding other financial issues With the help of better management we can prepare all the report for all management levels Amalgamation and reconstruction process of various companies supported by accounting principles and stander With the help sound management system we prepare the budget according to the need of business with the help of art of accountancy we maintain the record of financial record of all financial instruments like shares, debentures Management approach art help to calculation of costing of good sold With the help of better approach we can calculate the various type of cost which are very vital for the manufacturing sector like factory overheads and other cost which are essential for business world With the help of viable management approach we can prepare the reward report for labors like bonus plan and wages rates Good management policy help you to prepare the report of various department of various textile sectors Good management approach helps the man in other sector like leasing for the completion of term and conditions

Sound business management system is very beneficial for the client regarding establish of good relation and maintain of accuracy of all transactions Better business management system help you to estimate the risk in business between the events Calculation of risk provide the stander of accuracy between the events Good business management ideas helpful for the services sector of one country With the help of viable we can measure the monetary value of services In the light of arguments it can be said good business management system accountant is very beneficial for the country economy Good business management span helps the gathered the data about Country performance in economic sectors We can measure the total income of the country and estimate all the monetary value of all the services sector like telecommunication and energy sectors Good better and viable management system approach helps the country to value the balance of trade in monetary value with the rest of world Balance of payment is very crucial for every country sound [1-16].

\section{Economic Perspective}

Business management system help you to estimate the monetary value of balance of payment with rest of world Accountancy helps the country on the macro level and micro level Thus, we can say every government should encourage the profession of management consultancy. Government should establish such vocational institutes which provide the training to the management consultancy. Because of the role of best management practice transparency can be brought in the management matters Accounting system provide the opportunity transparency and true and fairness and accuracy of the all the affairs of business. The role of management consultant in business management system. Management consultant analyzes the market. Management consultants management consultant arrange the fund for finance. Management consultant negotiations with financial 
institution regarding loan Finance manager negotiations with lease institution. Management consultant draw the budget according to the resource of business. Management consultant makes decision of investment according to the operation of business. Management consultant makes trend analyzes. Management consultant have the proper survey regarding the stock market. Management consultant performs the role of company secretary. Management consultant call the Annual general meeting and extra ordinary general meeting. Management consultant publish the notice of annual general meeting. Management consultant files the annual return in security and exchange commission. Management consultant submit all relevant form which is required by corporate laws. Management and corporate consultant arrange the mediation when some conflicts arise. Management consultant arrange the ratio analyze for the view of financial positions. Management consultant play role regarding the impairment of assets. Management consultant analyze the risk between the event. Management and corporate consultant forecast of financial position. Management consultant give decision regarding the operation management. Management and corporate consultant arrange the investment opportunities for the company. Management and business consultant conduct the audit according to the legal requirement. Corporate consultant arrange the better flow of funds. Management and corporate consultant prepare the financial report according to the international stander. Corporate consultant prepare the cash management. Management consultant draw the master budget according to the company needs. Management and corporate consultant look after all the procedure of allotment of shares. The auditor can perform the role with the possible of good management system when we have the good management and corporate system the auditor audit the accounts properly according to the companies rules. it is essential that the accounts should be prepared according to the corporate laws. In the present of good management skills. In the present of good business management system there will be no qualification. With the good business management system auditor establish the opinion the investment was incurred according to the purpose, which is stated in the corporate laws. Auditor may find can transaction is held is transparent and good in the presence of good corporate and management system audit can easily check the expenditure according to the purpose. With the help of good business management system that director and other high management not run according to the own interest. Auditor checks the flow of investment with the help of good business management system. Auditor easily check that amount posted in relevant accounts properly. With the help of good business management system auditor check the banking transaction and match with bank. During the good business management system auditor verify all the agreement with vendors, auditor check that the business is being run by the management of company according to the proper term and conditions

Auditor can check the tax deduction of on various payment. Auditor checks the originality of transactions with the help of good business management system. With the help of good business management system that the payment is verified according to rules. with the help of good business management system we stream line all transaction of business. Auditor checks the employee welfare system with the help of good business management system, that all the payment is being deposited according to the rules and regulations. Auditor can point out all the mistakes according to the audit frame work. With the help of good business management system that the directors or any other high officer of company influence the business decision. In the presence good business management system auditor audit verify the stock according to the rules and regulations Auditor can give the advice regarding the business operations. In the presence of good business management system auditor checks the expenditure incurred according to the companies laws. In the present of good business management system auditor devalue of asset, according to the rules and regulation of assets regulation which is expressed in the corporate laws. During the good business management system auditor check and verify that companies management comply all the regulation of the corporate and companies laws. Auditor checks the statutory books of company In presence of good business management system. Auditor check that management consultant use the investment according to the purpose. In the present of good business management system the Auditor estimate all the resource including finance and corporate Finance. Management consultant response on the notice of tax department and security and exchange commission of country. Taxation is the important part of country economy. Management system help the both tax payer and government side to build system. with the help of good business management system we can calculate the taxable income easily and accurately. Good business management system help to calculate the head of total income. with the help of good business management system we can calculate the exemption in tax income. With the help of accounting system we calculate all average relief which accurately mentioned in taxation laws. we evaluate the value of assets according to laws. Good business management system helps the corporate consultant regarding the file of return Association of person. With the help of good business management system is very beneficial when the tax is deducted by the authority. With the help of good business management system the tax on goods and services easily calculated. In case when we file the appeal against the tax authority decision good business management system help in this regard. Statement which is filed by the taxpayer time to time good business management system help in this regard. Good business management system create the good relation between the customer and management Good business management system system help the customer when they needed some information the customer when they needed some information regarding tax and finance Good business management system provide the opportunity to customer regarding the reconciliation of financial matters Some time customer preserve the financial information for own purpose 
good business management system system help in this regard some time during assessment year tax payer want some information. In the case of Sue the claim of over tax liability Good business management system help the calculation in wealth tax. Good management system help the valuation of assets. Wealth tax liability can be easily calculated with the help of good business management system. Various statement can be acquired be by the tax authority can be properly filed with the help of good business management system. Wealth statement is mandatory for all the taxpayer proper data can be filed in the presence good business management system. Good business management system is beneficial for the calculation of sales tax. correct input and out put can be calculated with the help of good business management system. Drawback of duties can be only possible if we have good business management system. Good business management system help in the calculation of final sales liability. Custom duties are the integral part of taxes In the light of good business management system, calculation of duties is straighctforward. There is no chance of evasion of duties when the good business management system system is exit. Good business management system help the importer and exporter valuation of good under the relevant custom law of country. In the presence of good business management system we can fight the legal case of duties easily. Good business management system system maintain all the record of custom duties and tariff. In the case of draw back of duties the claim is in the present of good business management system. Excise duties are also the important part of taxation system, reliable accounting record helps in how the excise duty is leveled a various item. Good business managemen system $\mathrm{s}$ shows the payment of payment of excise duty properly Thus, we can good business management system help the government and taxpayer. In the economic survey side good management system how to get the proper price properly of various goods. with the help of proper application of management principles we can get the proper sample size of various classes of goods. sound management practice helps the importer and exporter to maintain the accounts both exporter and importer maintain the account which the good are delivered and accepted. Both exporter and importer record the expenses. sound management practice very beneficial for both parties that reconcile accounts and other issues easily. Because of modern practice of business management system both calculated the abnormal and normal losses. Good business management system system help the reconciliation between the head office and factory The benefit of that there is no chance of fraud between the head office and factory. Good business management system system provide the opportunity of consolidation of accounts in that case if your company are the parent and subsidiary or parent of other company, we can easily merge our account and get the maximum profitability of business. Good business management system help the business entity to implement on the accounting and reporting stander. The benefit of that maintain of accounting according to corporate laws which is exit in country In that case if two business entities on common objectives, They can easily maintain the joint venture account. In joint venture account both parties record the transaction of business according to business nature. In Good business management system rectify the wrong entry according to the rules and regulations when the good business management system system exit we can calculate cost volume analysis. Good business management system helps built the effective cash flow statement. Cash flow statement consists on operating investing and financing activities. cash flow system helps to calculate the profitability of business and budgeting of business. Good business management system evaluate of cost of good sold with invoice price. We can calculate the absorption cost with the sound business practice. Good business management system helps to calculate the present value method. Present value method calculate what is the present value of investment which are invested, with help of cash flow statement Good business management system helps the future value of investment. Future value investment determine the future value of investment. With the help of good business management system we can calculate internal rate of return Internal rate of return, express the highest rate of return. Good business management system helps regard the portfolio investment is very important for investor. In this investment the investors decide what proportion of investment is done in business activities. Good business management system guide how to deal with international financial institutes in exchange rate. Exchange rate is very important in international trade. international trade is very attach with exchange rate in international trade. All issues are settled including hedging and ups and down trend. With the good business management system we can get the better interest model which is important for finance management With the help of good business management system. Good business management system analyze the financial statement with the help of good business management system. we can analyze the financial statement at every time. Example of financial analyze final account, Bank reconciliation statements Income statement. Horizontal analysis trend and Vertical analyze trend analyze is very important for business, this analyze to help to estimate the financial position quarterly and annually. Analysis is very important for the company directors and shareholder Good business management system is very important for the corporate finance mean that companies subscribed the capital from the share holders and loan from the banking and financial institution With the help of modern management practice company manage the corporate finance easily and watch the back end resource how to safe this finance from risk factors. Right managerial treat meant of all corporate finance transaction is very essential. Sound management stance help how to manage the better return of corporate finance. Sound management practices system provide the break up of corporate finance. Good business management system help the better utilization of corporate finance according to the needs With the better management practice we can better utilization of resources. Better management system help how to reinvest in the various 
resource and calculate the expected rate of return. Good business management system system help the monitoring the all activities regarding the corporate finance Auditor are very aware with the activity of corporate finance with the help of good business management system. With the help of good business management system system we can calculate employee compensation easily calculated. Intangible assets are the important part of business operation With the help of role of managerial practices we can maintain the accounts of intangible assets. For example goodwill promoter expenses copy and patent right these are the very important for business. At the end of year we create the reserve just like depreciation of tangible assets with the help of sound management system we maintain the record of intangible assets. Cash con version policy is very important regarding business cycle some time we sold and purchase good on credit line with the help of better good management practices system we can watch the conversion policy easily. Cash conversion effect the working capital because it is direct to inventory. Cash conversion process is very important for every company cash conversion policy help the maintain of liquidity position. With the help of cash conversion policy we can predict the better financial position of company. If the company have not good conversion policy company face the serious melt down Thus we can say that better management policy system is only help to maintain the better conversion policy. Consolidated financial statement is the important part of business organization if company have the voting power in other company they can merge the accounts is own company accounts with the help of good managerial practices according to stander of international organizations. The benefit of that we can easily calculate the profitability easily. For example any company is the associate of parent company with the help of consolidation of accounts and sound management practices we can express the accounts of other company in one account statement Derivative are the very important part of business operation. Derivatives calculate the ups and down trend in the price it is only possible when we have accounts of certain transaction which is related to risk and other exchange rates if we have the table of business trend expected rate in the management form then we easily calculate and apply very easily derivatives. Derivatives are very important for macro and micro economics. Derivatives can only possible when we have data about the risk and expected rate of return in the managerial practice form. Only proper modern business management practices can help in this process of derivatives. Contingent liabilities and assets is the important part of company business without company sound modern business practices system we can easily maintain the record of continent assets and liabilities Contingent mean which is conditional some event. These are very important for business operation. For example one company agree on this conditions the company will not pay the credit according to the term and conditions they will pay the damages. In sound management practices system all this transaction should be recorded according to international stander of reporting. if company have the record of contingent liabilities and assets, company can sue the other easily because it is certified by the auditor and by the certified management consultant, if you have not the good business management system they will face the audit objection according to international reporting stander. Fair market value is the important part of business operations. Fair market price means difference between the price of good agree by purchaser and customer wailing The difference between the two price is called fair market value The record of market value policy is very important for management practices consultants when we have the record the both value, we can easily calculate the fair market price according to the business management stander. Human resource management is the integral part of business world. With the help of sound management system we can select the better candidates for job. Inthe presence of good management practice we can better use the man power according to the objective. With the help of better human resource system we can make the procedure for the selection of candidates we can easily evaluate the performance of any person. In the light of better management system we can appraise the candidates very well. With the help of good management practice we can make the good compensation policy according to the need of employee With the help of sound management policy we design the good relation ship model with employee. With the help of good management practice the reward incentive is given to employ. With the help of sound management system we should make policy regarding the facilities of employ. With the help of good management system the employer design such policy which give encourage employing. In the light of sound management practice the employer arrange the suitable working environment for employees. with the help of good business system the employer address the grievance of employee. with the tools of sound management system the employee give the security of job to employee. In the case distribute resolution the management should design such board which give decision regarding of employees. In the present of good management system the management arrange the training for employee. With the help if good Business management the professional courses for employee. With the good management practice the company can built the good relation ship with employee. with the help of sound management practice the management of company can easily implement the industrial relation laws. with the help of business management the employer can gain the result according to the objective. With the help of good management practice employee can easily maintain the principles With the help of good management practice employer can review the performance very wall. In the presence of good management practice the employer can design the good matrix of organization. With the help good management employer motivate the employee easily. With $h$ the help of good management system employee can discourage the attitude of unfavorable. In the present of good business management practice the employee formulates sound benefit policy for employee. In the presence of good business management flow of communication between the 
employee and employee is very fine. Under the system of sound management system the employee over come all the problem which is related to employee. With the help of sound system of management employee can create the culture of team work in the organization. With the help of sound management approach the employer can get the good outcome of job. with the help of effective management approach the employee can get the relation with trade union leader ship. Sound management approach direct the employ to start the welfare pro Project for welfare. in the present of good management system the employer introduce the system of promotion among the employee. During the good management approach employee introduces the department which measure the capacity of employee. Good management system are very help to regard the satisfaction of jobs. With the help of sound management system we can introduce the new talent in company. Good management help the employee to give the suggestions regarding upgrade of human resources of system. Good management system are very help for such employees who want creativity in the work. With the help of sound management system the employee makes the plain for overall development. Good business management system promote the effective unionism in the organization. With the help of sound management system the employee introduce the better system of placement in the organization. with the help of sound management system employee introduce the worker participants funds according to the need of employees. With the help of sound management system we can adopt the principles of comprehensiveness of polices. It is means that policy of human resource design such policy which cover all the aspects of organization. with the help of sound management system employee can adopt such police which have the aspects of continuous. In the presence of good management system the employee can adopt such polices which have the creativity of ideas for the employee. with the help of sound approach of management system we can the approach of commitment and correctness and effectiveness it is only possible when we adopt the sound and modern approach management system.

Business management education is crucial for every society without professional education no country can be developed. With the help of business management the better stander of performance can be achieved. Business management education can bring the culture of accuracy in all functions. Business management education can bring the revolution in the society. Business management education can increase the productivity of resources. Professional business education pattern is honorable for the country. Professional business education produce the professional attitude in human capital. Professional business education holder person can be proved very beneficial for whole world one professional business manager can be formulated the good business planning. Professional business education bring the creativity in work. Professional business education give the professional recognition to the person. Professional business education provide the opportunity of continuous professional development.
Organizations provide the route of development of services Professional organization give guidance to member how the value added services is performed. Professional business management consultant organization give guidance how the business operation can be improved [1-16].

\section{Conclusion}

Management are very important for one society. We can achieve the goal of economic development with the help of good management. Business management can provide the better way which goes to path of Development. Developed countries paid special attention to the management qualifications. Management management create the real opportunity for every person that he can play the role in the development of country and promote the corporate culture in the country.

\section{References}

[1] Scientific management theory since 1945. UNC Press Books. DuBrin, Andrew J. (2009). Essentials of management (8th ed.) Mason, OH: Thomson Business \& Economics. ISBN 978-0324-35389-1. OCLC 227205643.

[2] DuBrin, Andrew J. (2009). Essentials of management (8th ed.) Mason, OH: Thomson Business \& Economics. ISBN 978-0324-35389-1. OCLC 227205643.

[3] Waring, S. P., 2016. Taylorism transformed: Scientific management theory since 1945. UNC Press Books.

[4] Xenophon (1734). "Oikonomikos. Oder Xenophon vom HausWesen, aus der Griechischen- in die Teutsche Sprache übersetzet von Barthold Henrich Brockes, dem jüngern. Mit einer Vorrede S. T. Herrn Jo. Alb. Fabricii... Nebst den wenigen Stücken, die aus der Lateinischen Uebersetzung Ciceronis noch übrig".

[5] "Home: Oxford English Dictionary".

[6] SS Gulshan. Management Principles and Practices by Lallan Prasad and SS Gulshan. Excel Books India. pp. 6-. ISBN 97893-5062-099-1.

[7] Deslandes G., (2014), "Management in Xenophon's Philosophy: a Retrospective Analysis", 38th Annual Research Conference, Philosophy of Management, 2014, July 14-16, Chicag.

[8] Powell, Thomas C. (2001). "Competitive advantage: logical and philosophical considerations". Strategic Management Journal. 22 (9): 875-888. doi: 10.1002/smj.173. ISSN 10970266 .

[9] Langfred, Claus (2000). "The paradox of self-management: individual and group autonomy in work groups". Journal of Organizational Behavior. 21 (5): 563-585. doi: 10.1002/10991379 (200008) 21: 5<563: AID-JOB31>3.0. CO; 2-H.

[10] Wood, Robert; Bandura, Albert (1989). "Social Cognitive Theory of Organizational Management". The Academy of Management Review. 14 (3): 361-384. doi: 10.2307/258173. ISSN 0363-7425. JSTOR 258173. 
[11] Lumineau, Fabrice; Oliveira, Nuno (2017). "A Pluralistic Perspective to Overcome Major Blind Spots in Research on Interorganizational Relationships". Academy of Management Annals. 12 (1): 440-465. doi: 10.5465/annals.2016.0033. ISSN 1941-6520. S2CID 148825815. Administration industrielle et générale - prévoyance organization commandment, coordination - contrôle, Paris: Dunod, 1966.

[12] Jones, Norman L. (2013-10-02). "Chapter Two: Of Poetry and Politics: The Managerial Culture of Sixteenth-Century England". In Kaufman, Peter Iver (ed.). Leadership and Elizabethan Culture. Jepson Studies in Leadership. Palgrave Macmillan (published 2013). p. 18. ISBN 978-1-137-34029-0. Retrieved 2015-08-29.

[13] Vocational Business: Training, Developing and Motivating
People by Richard Barrett - Business \& Economics - 2003. p. 51.

[14] Compare: Holmes, Leonard (2012-11-28). The Dominance of Management: A Participatory Critique. Voices in Development Management. Ashgate Publishing, Ltd. (published 2012). p. 20. ISBN 978-1-4094-8866-8. Retrieved 2015-08-29.

[15] Harper, Douglas. "management". Online Etymology Dictionary. Retrieved 2015-08-29. - "Meaning 'governing body' (originally of a theater) is from 1739."

[16] See for examples Melling, Joseph; McKinlay, Alan, eds. (1996). Management, Labour, and Industrial Politics in Modern Europe: The Quest for Productivity Growth During the Twentieth Century. Edward Elgar. ISBN 978-1-85898016-4. Retrieved 2015-08-29. 